\title{
Bráðameðferð kransæðastíflu: pegar mínútur skipta máli
}

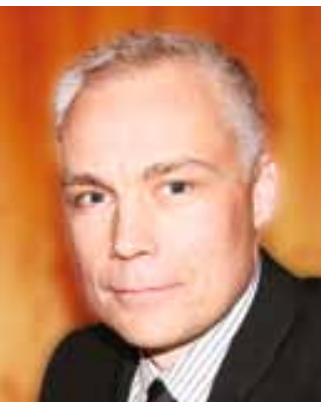

Karl Andersen

andersen@landspitali.is

Höfundur er hjartalæknir.

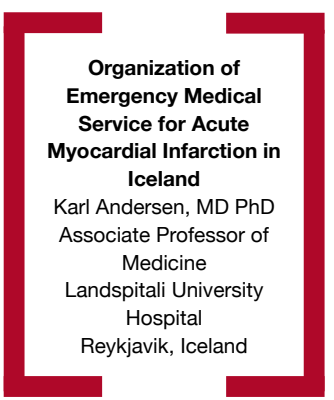

Beint samband er á milli tímalengdar kransæðastíflu og umfangs vefjaskemmdar sem af henni hlýst. ${ }^{1}$ Petta endurspeglast í pví að lífslíkur sjúklingsins minnka eftir pví sem lengri tími líður par til blóðflæði kemst aftur á. ${ }^{2}$ Ávinningur af enduropnun kransæða er langsamlega mestur á fyrstu 2-4 klst eftir upphaf einkenna. Hver mínúta sem sparast á pví tímabili er mun dýrmætari í að bæta horfur en pegar lengra er liðið frá áfalli. ${ }^{3}$

Bráðapjónusta við sjúklinga með kransæðastíflu hefst pegar sjúklingur með bráða brjóstverki kemst í samband við heilbrigðisstarfsfólk. Мeð réttum faglegum viðbrögðum má hefja meðferð strax og undirbúa komu sjúklingsins á sjúkrahús par sem sérhæfð meðferð með kransæðavíkkun (PCI) getur farið fram. Til pess parf að vera til staðar vel pjálfað starfsfólk heilbrigðispjónustu og sjúkraflutninga, tæknilegur búnaður til að senda rafrænt hjartalínurit (EKG) og vel búið sjúkrahús með sólarhringspjónustu. Allar pessar aðstæður eru fyrir hendi fyrir suðvesturhorn landsins á Landspítala í Reykjavík. Á landsbyggðinni eru sjúkrastofnanir sem hafa alla möguleika á að veita bráðameðferð við kransæðastíflu með segaleysandi lyfjum. Valið stendur pví á milli pess að beita segaleysandi lyfjameðferð strax í héraði eða flytja sjúklinginn á Landspítala til meðferðar með kransæðavíkkun. Við ákvörðun um pað hvora aðferðina eigi að nota er nauðsynlegt að gera sér grein fyrir pví hversu langur tími fer í flutninginn milli sjúkrahúsa og vega pá meðferðartöf sem af flutningnum hlýst á móti peim ávinningi sem næst með tafarlausri meðferð í héraði. Rannsókn í pessu tölublaði Læknablaðsins er mikilvægt framlag í pessari ákvörðunartöku. Í meginatriðum sýna niðurstöðurnar að:

- $\quad$ Flutningstími frá norðurhéraði er of langur til að réttlæta kransæðavíkkun sem fyrstu meðferð kransæðastíflu.

- $\quad$ Tími frá fyrstu komu til læknis og par til segaleysandi meðferð getur hafist er mjög stuttur í norðurhéraði.

- $\quad$ Stórt hlutfall sjúklinga með bráða kransæðastíflu fær ekki bestu lyfjameðferð fyrir komu á sjúkrahús.

Alpjóðlegar klínískar leiðbeiningar mæla með pví að kransæðavíkkun sé beitt sem fyrstu meðferð við bráðri kransæðastíflu á peim sjúkrahúsum par sem nægilegur tæknibúnaður og pjálfun starfsfólks leyfir. Sé mismunur á peim tíma sem tekur að hefja segaleysandi meðferð annars vegar og kransæðavíkkun hins vegar meiri en 60 mínútur er mælt með pví að nota segaleysingu, enda hefur viðbótarávinningur af kransæðavíkkun glatast við lengri meðferðartöf.
Tímalengd frá komu á sjúkrahús par til kransæðavíkkun eða segaleysandi meðferð fer fram er ásamt dánartíðni sjúklinga notaður sem alpjóðlegur mælikvarði á gæði og árangur meðferðarinnar í hverju sjúkrahúsi. ${ }^{1}$ Alpjóðlegar leiðbeiningar segja fyrir um að stefnt skuli að pví að meðaltal tíma frá komu á sjúkrahús par til kransæðavíkkun hefst (door-to-balloon time, D2B) sé innan við 90 mínútur. Pessi tími er styttri á sjúkrahúsum par sem kransæðavíkkanir eru gerðar en lengri pegar flytja parf sjúkling á milli húsa.

Mikil áhersla hefur verið lögð á pað víða um heim að bæta vinnulag og verkferla við flutning og meðferð sjúklinga með bráða kransæðastíflu. Rannsókn á pví hvað einkenndi pau sjúkrahús sem náð höfðu hvað bestum árangri í að stytta D2B tíma og bæta horfur sjúklinga sýndi að skýr markmiðssetning stjórnenda, gerð verklagsreglna, myndun sérhæfðra teyma starfsfólks, árangursmatskerfi og metnaðarfullt starfsumhverfi einkenndi pessi sjúkrahús öðru fremur. ${ }^{4}$

Á Landspítala er meðaltal D2B tíma 47 mínútur og eru $80 \%$ sjúklinga með D2B tíma innan við 60 mín. og 91\% minna en 90 mínútur. Dánartíðni á sjúkrahúsi var 1,7\% árið 2007. ${ }^{5}$ Dánartíðni kransæðastíflu innan 30 daga er 3,7\% og hefur farið ört lækkandi á undanförnum árum. Pessar árangurstölur Landspítalans eru með pví besta sem pekkist í heiminum. Til pess að tryggja аð meðferð kransæðastíflu verði áfram í fremstu röð er nauðsynlegt að vinna áfram að pví að bæta verkferla. Innlegg Björns Gunnarssonar og félaga er mikilvægt í pessa veru. Með fyrirhugaðri stofnun Hjartamiðstöðvar á Landspítala eftir fáeina daga hefur verið sköpuð аðstaða sem gerir íslensku heilbrigðisstarfsfólki kleift að veita bestu pjónustu sem völ er á í heiminum.

1. Gibson CM, Yuri BP, Paul DF, et al. Trends in reperfusion strategies, door-to-needle and door-to-balloon times, and in-hospital mortality among patients with ST-segment elevation myocardial infarction enrolled in the National Registry of Myocardial Infarction from 1990 to 2006. Am Heart J 2008; 156: 1035-44.

2. Antman EM. Time Is Muscle: Translation Into Practice. J Am Coll Cardiol 2008; 52: 1216-21.

3. Gersh BJ, Stone GW, White HD, Holmes DR, Jr. Pharmacological Facilitation of Primary Percutaneous Coronary Intervention for Acute Myocardial Infarction: Is the Slope of the Curve the Shape of the Future? JAMA 2005; 293: 979-86.

4. Bradley EH, Curry LA, Webster TR, et al. Achieving Rapid Door-To-Balloon Times: How Top Hospitals Improve Complex Clinical Systems. Circulation 2006; 118:1079-85.

5. Libungan B, Eyjólfsson K, Porgeirsson G. Bráđar kransæðapræðingar á Íslandi. Árangur á fyrsta ári sólarhringsvaktar. Læknablaðið 2008; 94: 103-7. 